Cartographies of scholarship: Stephen Heimans talks to Parlo Singh about teaching, research and the intellectual terrain of feminist scholarship with/after Bernstein 


\title{
Cartographies of scholarship: Stephen Heimans talks to Parlo Singh about teaching, research and the intellectual terrain of feminist scholarship with/after Bernstein
}

\author{
Parlo Singh is a leading contemporary sociologist of education and world- \\ renowned "Bernstein" scholar. In this interview with Stephen Heimans, Parlo \\ discusses important aspects of her teaching and research journey. She highlights \\ the interconnections between these and discusses her relationship with Basil \\ Bernstein's oeuvre and the work she has undertaken both that builds on and is \\ separate from it.
}

Keywords: theory; methodology; Bernstein; pedagogy

Stephen: Thank you Parlo for making the time to talk. At the recent ATEA conference you gave a keynote presentation called Research Codes and Teacher Education. I'm just wondering if we could discuss the work that you did there and maybe some of the broader contexts for that work. Could you start off by talking about how you became a researcher and then discuss perhaps some of the key theoretical and methodological ideas that you've used and how you put them into practice?

Parlo: I, like a number of my contemporaries, went through a publicly funded schooling system. And for me, education was my way out of poverty. I was the first in my family to complete tertiary education. I attended a College of Advanced Education to do a course in primary school teaching. In those days, in the late 1970s, teaching and nursing were considered acceptable careers for girls growing up in small country towns in North Queensland. The nearest tertiary education institution from home was about 6 hours travelling distance by bus, and so going onto higher education meant living away from home at a relatively young age. After gaining my teaching diploma, I taught in some rural and regional areas in North Queensland and felt that I had considerable professional autonomy, a fair bit of creativity in terms of my everyday teaching 
practices. As long as I worked within the confines of the syllabus, I could be creative in the way that I taught and worked with students. Students seemed to really enjoy my teaching and I gained recognition for my work from parents, other teachers, school leaders and school inspectors. I felt I was making a difference in students' lives and in the small, local community towns.

However, after I transferred to a teaching position at a primary school in Brisbane, I felt much more constrained in terms of my teaching work. I was really quite puzzled by these different sets of experiences. At the time, I was completing my Bachelor of Educational Studies part-time at a Brisbane University — and I found that I was reading a lot of the work of scholars in the disciplinary field of sociology of education.

My initial training — or education I should say—was at a College of Advanced Education. This was the first time I had ever attended a university. I was now reading sociology of education work, with a very strong Marxist tradition, and people arguing that education institutions weren't major change agents. In fact, these authors were arguing that schooling institutions reproduce unequal class structures ${ }^{(1-9)}$. That was a profoundly new insight for me, having come from a working-class background and viewing education as a way out of poverty. I started thinking about class and class systems and gender relations and that the teaching profession was female dominated, but men held most of the leadership/senior positions - school principals, inspectors, university lecturers/professors.

All of those ideas for me, in my early 20 s, were really quite radical ways of thinking about schooling. Actually, the ideas were unsettling to be honest, because I started then thinking about what I was teaching and how I was teaching. And once I started allowing myself to think along these lines, I couldn't keep teaching the way I 
had been teaching in the past. It became really uncomfortable to keep going through the rituals and routines of schooling work, the morning assemblies, the gendered staffroom conversations, teaching a restricted version of knowledge in the school curriculum. Another thing that troubled me at the time, this is the early 1980s, was the racialized talk in schools about non-white students and staff. I was often the only non-white teacher on staff.

Stephen: So, in terms of your own trajectory of thinking, then, I know you focussed a lot on Basil Bernstein's work...

Parlo: I think the reason why I became interested in Bernstein's work at that time was because I had read his work on classification and framing of knowledge and school curriculum $^{(5)}$. Remember, I had been teaching in a primary school. Bernstein was a sociologist writing about the thinkable and unthinkable in terms of valid school knowledge - what can be included, when, where, why and what cannot be included as valid school knowledge.

That notion of what is thinkable and unthinkable was really fascinating for me. Which group makes those decisions about what knowledge can be included in school curriculum? And how do struggles over school curriculum knowledge get played out? I was also interested in not only the content of school curriculum, what gets included in curriculum, and what is excluded, but also how the very organisation or structuring of curriculum effects students and a teacher's relation to the possibilities of thinkable and unthinkable. Bernstein had thought about these matters and mapped out different modes of curriculum organisation in the English schooling system. I wondered if there were similar patterns of curriculum organisation in the primary school where I was teaching. Bernstein's writing also helped me to think about different models of pedagogy because 
he differentiated between visible and invisible pedagogies, using a humorous narrative about the layout of lavatories to illustrate his case. I think I got his sense of humour ${ }^{(5)}$. I was still teaching in schools, trying to work out what's going on here for me? I felt like I was pushing against boundaries, symbolic boundaries, all these rules about what could be taught, when, and how. When I tried to question the rules, I was given no real reason or explanation, except that this is how it has always been done in this school.

So, I was interested in this diagram produced by Bernstein ${ }^{(10, \mathrm{p} .63)}$ in which he tries to model different types of pedagogies, because at this stage, I had become interested in the literature around critical pedagogies, anti-racist pedagogies and feminist pedagogies.

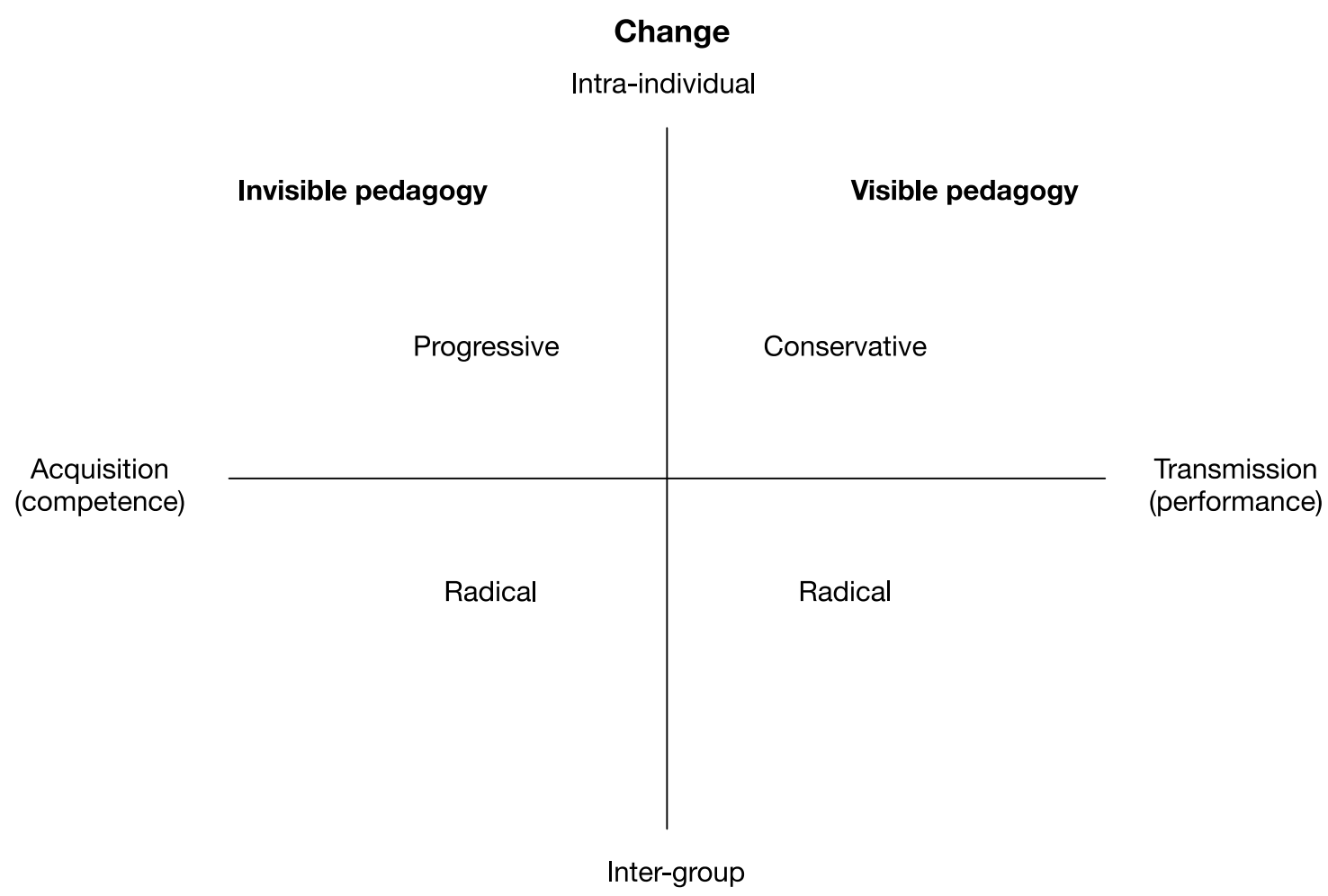

Figure 1. Modelling pedagogy

In this model, the vertical axis focuses on the site of change, at one end of the continuum change is centred within the individual (intra-individual), on the other end it is centred at the level of the social group (inter-group). The horizontal axis focuses on 
knowledge - at one end of the continuum the teacher is more visible in the knowledge relation process, and the other end, the teacher is less visible, and the focus is on learners, learning. Bernstein did not advocate for one model over another. Rather, he argued that despite the labels of progressive, conservative and radical each model of pedagogy could potentially reproduce or interrupt patterns of social inequality. The potentialities of these different pedagogies for social change and addressing issues of educational inequality depended on: (1) initial teacher education and the on-going education for teachers; (2) time, resources, and collective support given to teachers to design lessons; (3) professional autonomy to construct lessons that connect to the experiences and learning needs of students.

The crucial point for Bernstein was looking at the power relations that structured the message systems of schooling.

But, so what about power relations? The power relations were directly related to the work of different middle-class factions trying to exert their models of curriculum, pedagogy and evaluation in the education system and thereby giving their children the necessary cultural codes/resources to reproduce their class position. So here, Bernstein is relating curriculum, pedagogy and evaluation in schooling to the social division of labour outside of schooling. He focuses specifically on the work of people employed in various professions, the middle-classes. And then he looks at the types of work they do, the knowledge they have acquired to do this work, and how they might then advocate for this type of knowledge to be taught in schooling. From this perspective, curriculum, pedagogy and evaluation are sites of power struggles between different middle-class factions to ensure that the schooling system maintains and reproduces their position within the class structure. It is in this way, that factions of the middle class ensure that cultural capital and resources are passed down to their children. So, while, the upper 
class pass on material resources (land, money, goods), the middle classes are dependent on passing down cultural resources (habits, dispositions, education credentials) to maintain their position in the social division of labour.

Stephen: That's interesting, so Bernstein actually impacted on your practice as a teacher initially.

Parlo: Yes. Bernstein had written a number of articles and one was titled: A Critique of the Concept of Compensatory Education which was published in one of his books ${ }^{(7)}$. From that article, I got the idea that it's a myth to think that all the work that I was doing in schools was going to make a huge difference when there are all these other social inequalities outside of schools, as well as constraints within schooling which limit the possibilities of the thinkable, actionable, doable. Schooling is only one institution in creating or disrupting patterns of inequality. That to assume that an individual can make a huge amount of difference to a whole system of inequality is simply a fantasy.

Stephen: But, that's not to say that schools don't do some good things?

Parlo: Schools have the potential to do enormous things. My concern was more about what one individual could do. I was beginning to question the notion of the heroic individual making a huge difference, because part of my initial teacher training was centred around this idea.

Stephen: Okay, so can we then talk about Bernstein and your own research trajectory?

Parlo: Because I got to spend a bit of time with Basil Bernstein at the Institute of Education, University College London, I found the pedagogic experience with him different to anything I had experienced with supervisors and lecturers in Australia. I'd always been fascinated by being a teacher to be honest with you. I loved being a 
teacher. I loved being a primary school teacher. And I remember, there were some teachers in my own experience that I really enjoyed being with and learning from in that engagement. So, the pedagogic experience with Basil was a really-I don't know what I want to say—but it was a very enriching, let's use that word — a very enriching experience, because here was somebody that took my work really seriously. He would actually just sit there for a couple of hours deeply thinking and engaging with my work. I'm now talking about the late '80s_-it was '89. I remember that because it was the year the Berlin Wall fell. Basil would meet me regularly, sometimes twice a week, sometimes for two hours at a time. We would sit in his office and talk about my thesis. The talk would move around various topics: the data I had collected, the literature I was reading, and the concepts I was using to think about the thesis. Then, he would try to map some of our thinking into diagrams or models. So, working with Basil in that pedagogic encounter, became an exercise in thinking together. Basil also met regularly with the whole group of doctoral students he supervised for dinner in various restaurants in the Bloomsbury area. That's incredible — now I think back to it, what a privileged exercise. What a privileged experience to go through.

The only thing I think — and it's taken me a long time to step back—or step forwards, whatever, to think about that experience is something that Sarah Delamont ${ }^{(11)}$ wrote ages and ages afterwards. In fact, it was only about—I think she was writing it in response to all this work that has taken off after Basil Bernstein died. She wrote something to the effect of - perhaps all of these people are producing this work after Bernstein died because it was quite difficult to write it when he was alive, because he was such a big figure in the sociology of education.

Then she wrote about the long shadow of Bernstein. That if you've worked with somebody like Bernstein, who has kind of got fame and in some ways infamy, it's quite 
hard to step outside of his shadow. So instead of being known for your own scholarship, you get labelled as a Bernsteinian scholar.

Stephen: How would you position yourself then?

Parlo: Now? That's a very good question because at one level I feel very fortunate that I did have that pedagogic research experience that many people don't. In some ways I think of myself as being very fortunate to have that intellectual journey under his mentorship.

It's kind of a gift in many ways, but also then is there any possibility for me to stand—step outside of Basil Bernstein's long shadow? It's only through interactions with some of my feminist colleagues and yourself, Stephen, that I've thought Basil was actually pushing me to develop my own agenda 20 years ago. For example, Basil Bernstein wrote "[o]f considerable interest was that Singh showed the inadequacy of the theory to describe and interpret the process of production, fixing and canalising of desire' (p.120) ${ }^{(12)}$. So, he had been writing about the limitations of his ideas in relation to thinking about different research problems, and the importance of researchers to keep developing new concepts, new models.

Stephen: But so just to push back on that a little bit further, because I know recently you've also developed some of the Bernstein stuff a bit further through the psychoanalytic, object relations literature. Is that the right word?

Parlo: I think my interest—-sustained interest in the Bernstein work was that education research often isn't fashionable, or schooling research isn't fashionable, let's put it that way. Bourdieu did do research on schooling and produced the book: Reproduction in Education, Society and Culture ${ }^{(4)}$. 
Whereas with Bernstein, he has stuck with, and constantly gone back over the same issue over five volume of Class, Codes and Control ${ }^{(5,7,8,10,12)}$. He was always interested in social inequality through class and the role schools play in relation to disrupting, reproducing social inequality. He stayed with the same problem and kept trying to understand the complex ways in which institutions that claim to be about disrupting inequalities, also reproduce inequality. I actually quite like somebody staying with one project over 40 years, but also letting go some ideas and having to rethink and reshape ideas and think along different directions. I think that's something quite impressive. So, I think the pedagogic encounter of working with Bernstein was significant for me, it had lasting affects/effects because it was a thinking together journey. And so, when I read and re-read his work, it takes me to that pedagogic encounter, a pedagogic thinking journey.

Stephen: Do you think Bernstein saw the effect of his work in schools?

Parlo: No. No. That was a very quick response wasn't it? The first time I introduced Bernstein's research myself to my students was when I was teaching a Master of Education class. I had to construct my own curriculum for the course and so I introduced the students to two of Bernstein's papers: The Classification and Framing of Knowledge, and Visible and Invisible Pedagogies ${ }^{(5)}$. The class included mainly primary and secondary school teachers who were studying part-time and coming to classes in the evening. I was really quite surprised in some ways, because most of the students still related to those two papers. They connected with the ideas. They could see that the ideas helped them to think about was happening in their schools.

Stephen: Surely all of that scholarship was about creating change in schools?

Parlo: That's a very good question. I don't know. I think Bernstein thought of himself as 
a theoretician. He had been a Director of the Sociological Research Unit at the Institute of Education, University of London and was doing a lot of empirical work in the 1970s - nearly 50 years ago. At the time, Bernstein was operating within a dominant model of 'scientific research'. The way he thought about scientific work was to develop a theory, underpinned by a set of hypotheses, model what he thought he might find, then collect empirical data, and then think about how the data findings align with the theory/models. This process provided the condition for growth or refinement of the theory. Bernstein, like his contemporaries at the time, was interested in producing a 'grand theory' - a theory that could explain the evolution of education systems, teachers' work, the organisation of curriculum, pedagogy and evaluation. All of this was designed to answer the central problematic around the role of schooling in reproducing or disrupting patterns of social class inequality. In other words, he was trying to develop his thesis that schools played an active role in 'failing' working class children, despite advocating that they rewarded individual students on the basis of inherent talent and merit. Policy struggles over curriculum, pedagogy and evaluation are not about ensuring equal educational outcomes for working class students. Rather these struggles are between different factions of the middle class and related to ensuring that their cultural ideas/ideals are taught in schools.

However, Bernstein's latter scholarship, particularly scholarship that engaged with the philosophical work of Foucault ${ }^{(13-17)}$, was built on work he did with his doctoral students. And because he was based in London, he did supervise research students from across the world. So, I suspect that Bernstein's legacy lives on not only in the five books $^{(5,7,8,10,12)}$, but through the deep pedagogic encounters he had with these research students, and their engagements with their students. Bernstein did believe in the power of pedagogy for change, and so the pedagogies he enacted with his own research 
students, was about putting into practice this change. I can think about this through recent, psychoanalytic literature that talks about a third entity, third space, a field generated in the psychoanalytic encounter between analyst and analysand. A number of psychoanalytic theorists writes about how the intrapsychic and interpersonal experience in the encounter between two minds, analyst and analysand, generates the third entity of the 'emotional field' or 'analytic third'. Experience unfolds in this analytic third at multiple levels, corporeal, conscious, unconscious, emotional, sensory for both participants engaged in the analytic encounter leading to the emergence of new becomings ${ }^{(18-20)}$. Now in terms of teaching, a teacher can exist in relation to a student, and in terms of research, a researcher can only exist in relation to the researched. So, what takes place, emerges during these encounters?

In the pedagogic encounter with Bernstein as teacher, a third entity or field was enacted around research as a 'thinking together', being and becoming together journey. This field was comprised of the teacher, student, books, maps, models, and the international community of doctoral students and scholars. This field lived on after Bernstein the man passed away and took various forms, an international symposium held every two years, conference symposium, and an ongoing legacy of thinkingtogether work. I'm not sure, but I think that this might be his greatest legacy. But there are other ways that his work had direct impact in schools. The systemic functional linguistic scholars, Michael Halliday ${ }^{(21,22)}$ and Ruqaiya Hasan ${ }^{(23-29)}$, were in ongoing dialogue with Bernstein's sociology and their work, as well as the work of their students and colleagues ${ }^{(30-38)}$ was directly incorporated into schooling systems across the world in the design of curriculum, pedagogy and assessment.

Stephen: Wow, okay. Just going back to the purposes of research, and maybe you can talk about this with respect to Bernstein and with respect to you, so what did Bernstein 
posit as the purposes of research?

Parlo: Before I can talk about the purposes of research, I need to think about what research is. Bernstein wrote about the importance of producing new knowledge in scientific inquiry, something that was NEWS, a new way of thinking about things. He was highly critical of the current research economy, arguing that it has generated a research culture which does not encourage 'theoretical innovation or methodological disturbances $^{\text {(12 p.132) }}{ }^{2}$ Bernstein also wrote about the 'conceptual syntax' of theory suggesting that "we should recognise it for what it is, something good to think with, or about. It may alert us to new possibilities, new assemblies, new ways of seeing

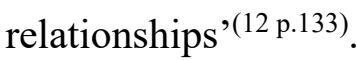

So, I have taken on some of Bernstein's ideas about research in my own work. But I am also interested in extending this idea about 'the new' to what new emerges in and through research encounters. So, while Bernstein wrote about the conceptual syntax of theory as something good to think with or about, I am interested in what emerges through this thinking/listening work, not only the artefacts, objects that might emerge, but also new ways of being, new social relations, and figurations. So, this is my journey in terms of the theoretical innovation and methodological disturbances mentioned by Bernstein in the above quote. Research, for me, is also a 'democratic right' ${ }^{(39,40)}$, just as is educational equality through free, publicly funded schooling systems.

Stephen: That's interesting. Is there a connection there through to Marx? I mean, because Marx had a particular way of thinking about the relationships between philosophy, science and social change?

Parlo: Let me think out loud. The interesting thing about Bernstein is that many constructed him as a radical scholar. I often wondered why they thought he was a 
radical scholar. I suspect it is because he did not follow intellectual fashions. He drew on the ideas of sociologists Marx, Durkheim, Weber, Mead (symbolic interactionism), as well as linguists (Halliday), psychoanalytic material (Luria) and cultural psychology (Vygotsky). And while he had a traditional view of science, theory first, hypothesis, empirical data, modelling and so forth, as he engaged in pedagogic thinking work, he often operated at the level of intuition and instinct.

Stephen: Okay. What about you then?

Parlo: In the early days I thought research was about truth finding in the pursuit of social justice. I was going to find the truth about the role schools played in re/producing inequality almost like an investigative form of journalism. That was what the job of a researcher was supposed to be about—uncovering, unmasking what was really going on in schools in terms of addressing issues of social inequality. If the purpose of research was about unmasking what was really going on in schools, and somehow, I could do this unmasking work through the tools and trade of research, then my job was to research and publish in the best journals in my disciplinary field.

At the same time, I have worked on various 'partnership projects' over the past few decades with colleagues working on anti-racist and gender equity policies ${ }^{(41-50)}$, and with colleagues working on improving literacy outcomes for students attending schools in high poverty communities ${ }^{(51-61)}$. But despite the heavy investment in these projects educational inequality persists and seems more deeply entrenched.

So, I have wondered/pondered about the purposes of research. And it has taken me back to the pedagogic encounters with Basil, the thinking-together work, and I suspect that this is the lasting legacy Basil Bernstein left me with. Research is about a thinking journey between researcher and researched which generates a third thing, space, object, field. And it is this research field that changes both researcher and 
researched and allows for the emergence of new possibilities, for reaching towards the unthinkable.

My research investments now are in long-term projects with doctoral students and working in and with school staff. Such long-term investments provide the opportunity (time, space, resources) for the thinking-together work of pedagogic and research encounters.

\section{Acknowledgement}

Funding for the research project described in this interview were provided by Australian Research Council Discovery Project, DP160102784.

\section{References}

1. Apple MW. Does education have independent power? Bernstein and the question of relative autonomy. British Journal of Sociology of Education. 2002;23(4):60716.

2. Connell R. Markets all around: Defending education in a neoliberal time. In: Proctor H, Brownlee P, Freebody P, editors. Controversies in education: Orthodoxy and heresy in policy and practice. Heidelberg: Springer; 2015. p. 18198.

3. Connell RW. Making the difference, then and now. Discourse: Studies in the Cultural Politics of Education. 2002;23(3):319-27.

4. Bourdieu P, Passeron J-C. Reproduction in education, society and culture. London: Sage; 1990.

5. Bernstein B. Class, codes and control: Volume 3. Towards a theory of educational transmissions. London: Routledge \& Kegan Paul; 1975/1977. 
6. Bernstein B. Sources of consensus and disaffection in education. In: Bernstein B, editor. Class, codes and control: Volume 3. Towards a theory of educational transmissions. 2nd ed. London: Routledge; 1977.

7. Bernstein B. Class, codes and control: Volume 1. Theoretical studies towards a sociology of language. London, New York: Routledge, Taylor and Francis Group; $1971 / 2003$.

8. Bernstein B. Class, codes and control: Volume 2. Applied studies towards a sociology of language. London, New York: Routledge, Taylor and Francis Group; 1973/2003/2005.

9. Bernstein B. Language and social class. British Journal of Sociology. 1960;11:271-76.

10. Bernstein B. Class, codes and control: Volume 4. The structuring of pedagogic discourse. London, New York: Routledge, Taylor and Francis Group; 1990/2003.

11. Delamont S. The heavy shadow? Bernstein and his legacy. British Journal of Sociology of Education. 2014;35(3):469-74.

12. Bernstein B. Pedagogy, symbolic control and identity. Theory, research, critique. Revised ed. 2nd ed. Lanham, Boulder, New York, Oxford: Rowan \& Littlefield Publishers, Inc; 2000.

13. Foucault M. The archaeology of knowledge. London: Routledge; 1972.

14. Rabinow P. Ethics, subjectivity and truth. The essential works of Foucault 19541984. New York: The New Press; 1977.

15. Patton P, Morris M, editors. Michel Foucault: power, truth, strategy. Sydney: Feral Publications; 1979. 
16. Foucault M. Governmentality: Ideology and Consciousness (vol. 6). Eide, M. \& Knight, G.(1999). Service journalism and the problems of everyday life. European Journal of Communication. 1979;14(4):525-47.

17. Foucault M. Power/knowledge. Brighton, Sussex: The Harvester Press; 1980.

18. Ogden TH. On holding and containing, being and dreaming. International Journal of Psychoanalysis. 2004;85:1349-64.

19. Ogden TH. Creative readings: Essays on seminal analytic works. London, New York: Routledge, Taylor \& Francis Group; 2012.

20. Eaton J. Listening to yourself, listening to another. In: Eaton J, editor. A fruitful harvest: Essays after Bion. Seattle, WA: Alliance Press; 2011. p. 125-41.

21. Halliday MAK. Language as a social semiotic. London: Edward Arnold; 1978.

22. Halliday MAK. Language and the theory of codes. In: Sadovnik A, editor. Knowledge and pedagogy: The sociology of Basil Bernstein. New Jersey: Ablex Publishing Corporation; 1995. p. 127-44.

23. Hasan R. Society, language and the mind: The meta-dialogism of Basil Bernstein's theory. In: Christie F, editor. Pedagogy and the shaping of consciousness: Linguistic and social processes. London, New York: Continuum; 1999. p. 10-30.

24. Hasan R. Understanding talk: Directions from Bernstein's sociology. International Journal of Social Research Methodology. 2001;4(1):5-9.

25. Hasan R. The ontogenesis of decontextualised language: Some achievements of classification and framing. In: Morais AM, Neves I, Davies B, Daniels H, editors. Towards a sociology of pedagogy: The Contribution of Basil Bernstein to Research. New York: Peter Lang; 2001. 
26. Hasan R. Semiotic mediation and mental development in pluralistic societies: Some implications for tomorrow's schooling. In: Wells G, Claxton G, editors. Learning for life in the 21 st century: Sociocultural perspectives on the future of education. Oxford: Blackwell Publishers; 2002. p. 112-26.

27. Hasan R. Ways of meaning, ways of learning: Code as an explanatory concept. British Journal of Sociology of Education. 2002;23(4):537-48.

28. Hasan R. The concept of semiotic mediation: Perspectives from Bernstein's sociology. In: Muller J, Davies B, Morais AM, editors. Reading Bernstein, Researching Bernstein. London: Taylor and Francis, RoutledgeFalmer; 2004.

29. Hasan R. Literacy, pedagogy and social change: Directions from Bernstein's sociology. In: Moore R, Arnot M, Beck J, Daniels H, editors. Knowledge, power and educational reform: Applying the sociology of Basil Bernstein. London and New York: Routledge; 2006. p. 211-25.

30. Christie F. Pedagogic discourse in the primary school. Linguistics and Education. $1995 ; 7: 221-42$.

31. Christie F. Learning the literacies of primary and secondary schooling. In: Christie F, Misson, R, editors. Literacy and schooling. London, New York: Routledge; 1998. p. 47-73.

32. Christie F. Genre theory and ESL teaching: A systemic functional perspective. TESOL Quarterly. 1999;33(4):759-63.

33. Christie F, editor. Pedagogy and the shaping of consciousness: Linguistic and social processes. London and New York: Continuum.; 1999.

34. Martin JR. Mentoring semogenesis: 'genre-based' literacy pedagogy. In: Christie F, editor. Pedagogy and the shaping of consciousness: Linguistic and social processes. London: Continuum; 2000. p. 123-55. 
35. O'Halloran K. Mathematical and scientific forms of knowledge: A systematic functional multimodal grammatical approach. In: Christie F, Martin J, editors. Language, knowledge and pedagogy. London: Continuum; 2007. p. 205-38.

36. Christie F, Martin J, editors. Language, knowledge and pedagogy. Functional linguistics and sociological perspectives. London: Continuum; 2007.

37. Exley B, Singh P. Social Studies disciplinary knowledge: An Australian case study of tensions between state curriculum and national assessment in disadvantaged school communities. In: Christie F, Maton K, editors. Disciplinarity: Functional linguistic and sociological perspectives. London: Continuum; 2011.

38. Christie F, Maton K, editors. Disciplinarity: Functional linguistic and sociological perspectives. New York: Continuum 2011.

39. Appadurai A. The right to research. Globalisation, societies and education. 2006;4(2):167-77.

40. Appadurai A. Future as cultural fact: Essays on the global condition. New York: Routledge; 2013.

41. Singh P. Generating literacies of 'difference' from the 'belly of the beast'. Australian Journal of Language and Literacy. 1994;17(2):92-100.

42. Singh P. On speaking as an 'Asian' teacher. Gender and cultural inclusion in social education curricula. Education Links. 1997;54:11-6.

43. Singh P. Local and official forms of symbolic control: An Australian case study of the pedagogic work of para-educational personnel. International Journal of Inclusive Education. 2000;4(1):3-21.

44. Singh P. Speaking about cultural difference and school disadvantage. An interview study of 'Samoan' paraprofessionals in designated disadvantaged 
secondary schools in Australia. British Journal of Sociology of Education. 2001;22(3):317-37.

45. Singh P, Dooley K. Accounting for educational equality: The cultural politics of Samoan paraprofessionals' representations of pedagogy in state-designated disadvantaged schools and communities in Australia. Journal of Curriculum Studies. 2001;33(3):335-62.

46. Singh P, Sinclair M. Diversity, disadvantage and differential outcomes: An analysis of Samoan students' narratives of schooling. Asia-Pacific Journal of Teacher Education. 2001;29(1):73-92.

47. Singh P, Dooley K, Freebody P. Literacy pedagogies that may 'make a difference'. Asia-Pacific Journal of Teacher Education. 2001;29(1):49-71.

48. Taylor S, Singh P. The logic of equity practice in Queensland state education2010. Journal of Education Policy. 2005;20(6):725-40.

49. Singh P. Urban education, cultural diversity and poverty. A case study of globalization: Brisbane, Australia. In: Kincheloe J, Hayes K, editors. Metropedagogy: Power, justice, and the urban classroom. Rotterdam, The Netherlands: Sense Publishers.; 2006. p. 133-46.

50. Singh P, Taylor S. A new equity deal for schools: A case study of policy-making in Queensland, Australia. British Journal of Sociology of Education. 2007;28(3):301-15.

51. Singh P, Thomas S, Harris J. Recontextualising policy discourses: A Bernsteinian perspective on policy interpretation, translation, enactment. Journal of Education Policy. 2013;28(4):465-80. 
52. Singh P, Heimans S, Glasswell K. Policy enactment, context and performativity: Ontological politics and researching Australian National Partnership policies. Journal of Education Policy. 2014;29(6):826-44.

53. Singh P. Performativity and pedagogising knowledge: Globalising educational policy formation, dissemination and enactment. Journal of Education Policy. 2015;30(3):363-84.

54. Singh P, Märtsin M, Glasswell K. Dilemmatic spaces: high-stakes testing and the possibilities of collaborative knowledge work to generate learning innovations. Teachers and Teaching. 2015;21(4):379-99.

55. Singh P, Pini B, Glasswell K. Explorations in policy enactment: Feminist thought experiments with Basil Bernstein's code theory. Gender and Education. 2016;30(4):417-34.

56. Heimans S, Singh P. Re-presenting, performing critical/post-critical research realities. Research in Education. 2016;96(1):93-109.

57. Singh P. Performativity, affectivity and pedagogic identities. European Educational Research Journal. 2018 Jul;17(4):489-506.

58. Heimans S, Singh P, Glasswell K. Doing education policy enactment research in a minor key. Discourse: Studies in the Cultural Politics of Education. 2017;38(2):185-96.

59. Ivinson G, Singh P. Special issue on 'International policies - local affects: Regenerating the sociology of Basil Bernstein'. European Educational Research Journal. 2018;17(4):461-9.

60. Heimans S, Singh P. Putting the steam back into critique? 'Gathering' for criticaldissensual collaborations in education policy research. Policy Futures in Education. 2018;16(2):185-201. 
61. Rose J, Low-Choy S, Singh P, Vasco D. NAPLAN discourses: a systematic review after the first decade. Discourse: Studies in the Cultural Politics of Education. 2018:1-16. 